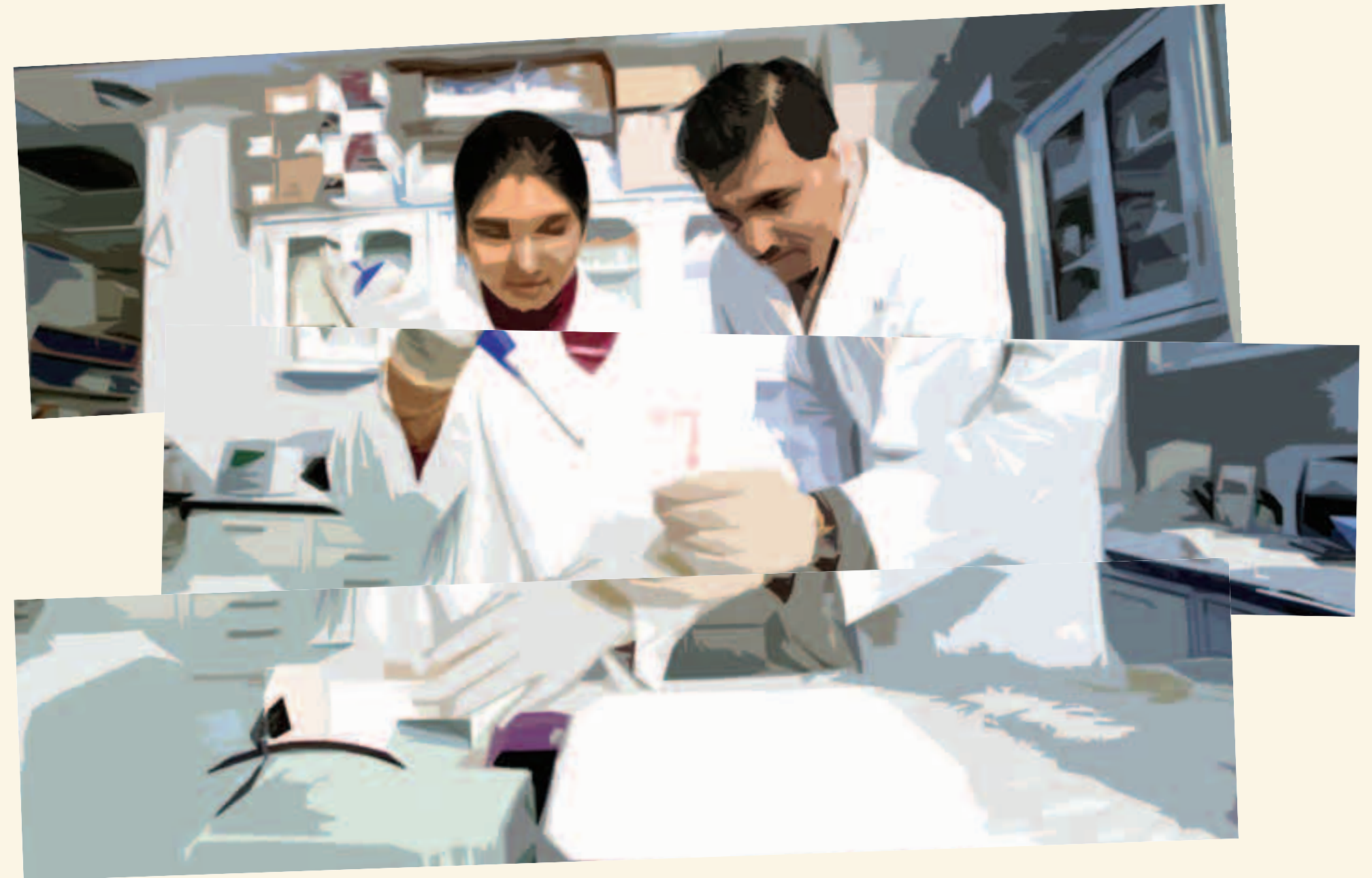

\title{
Docencia e investigación, una necesidad para la Universidad
}

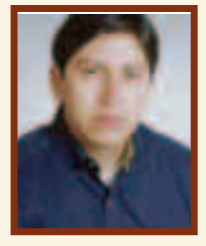

Químico Paco Noriega R.

Director de Carrera de Biotecnología de los RN.

En un café de la ciudad de Quito-Ecuador, con un amigo y profesor de una de las más renombradas universidades de la ciudad, discutíamos acerca de ¿cuál debería ser el papel del profesor universitario?, sobre todo, en lo que al área científica se refiere. Con tristeza rememorábamos nuestras viejas experiencias estudiantiles, y la casi omnipotente última palabra y posesión de la verdad, que nuestros profesores de antaño parecían tener.
Comentaba con mi compañero la experiencia personal vivida en Italia, cuando realizaba mi especialización y enfatizaba las diametrales diferencias que existían entre la vieja forma de llevar la docencia nuestra, frente a la dinámica forma de trabajo de la universidad del primer mundo.

Hice hincapié en lo referente a la prioridad que se daba a la investigación y a la forma de trabajo sistemático que los diferentes centros propiciaban, a manera 
de una sana competencia. El profesor entregaba a la Universidad la totalidad de su tiempo y la integridad de su conocimiento, y a cambio esta le facilitaba la posibilidad de tener todas las herramientas necesarias para mantenerse actualizado y en actividad. Era su obligación publicar por lo menos dos veces al año en revistas internacionales especializadas, empleando como material los trabajos hechos en el centro a su cargo, conjuntamente con un grupo de estudiantes pre y postgradistas que tenía a su disposición.

Luego de un largo discernimiento concluimos que, desafortunadamente, la gran mayoría de docentes en nuestro país cree que el dominio científico radica en el manejo y conocimiento de un texto guía, cuando hoy sabemos que un verdadero maestro debería manejar el conocimiento que día a día, se ve reflejado en las revistas científicas especializadas, que es donde realmente se halla la vanguardia de la ciencia; y que lamentablemente una especie de miopía nacional oscurece los ojos de autoridades, docentes y estudiantes.

La excusa para no trabajar en investigación, casi siempre está supeditada a nuestras carencias económicas, aunque es cierto que los recursos, ya sean estatales o privados son insuficientes, personalmente estimo que no es la única razón, por la que no iniciamos un trabajo verdadero en este sentido. Existen algunas falencias en el fondo mismo de nosotros, las que no nos permiten arrancar en investigación.

A continuación presento cinco publicaciones en las que consta la colaboración de la Universidad Politécnica Salesiana.

Dos de ellas realizadas en colaboración con el Dr. Marco Dehesa, quien fuera director de la Maestría para el aprovechamiento de los Recursos Naturales no tradicionales, en su primera edición, y que llevan por título:

1. Chemical Composition and Biological Activities of Ishpingo Essential Oil, a Traditional Ecuadorian Spice from Ocotea quixos (Lam.) Kosterm. (Lauraceae) flower calices

2. In vitro antioxidant and antibacterial activity of the essential oil of Amazonian Basil, Ocimum micranthum Willd., Labiatae. Journal of Ethnopharmacology, in press

Una realizada con la colaboración de la Dra. María Elena Maldonado, que actualmente es la directora del CIVABI (Centro de Investigación y Valoración de la Biodiversidad), cuyo título es:

3. Morpholigic and enzymatic characterization of fungi from amazonian forest soil (Ecuador). Mycological Research, spedito (2005)

Una realizada por el Químico Paco Noriega, director de la carrera de Biotecnología de los Recursos Naturales, en donde consta el nombre del laboratorio que la Universidad Politécnica Salesiana tiene en Sevilla Don Bosco (Macas), cuyo título es:

4. Essential oil of wild Ocotea quixos (Lam.) Kosterm. (Lauraceae) leaves from Amazonian Ecuador
$Y$, finalmente, una en colaboración con el Dr. Matteo Radice, docente del programa de Tecnología para el Aprovechamiento de los Recursos Biológicos Amazónicos, en representación de la Fundación Chankuap, ONG Salesiana vínculada al trabajo del proyecto, cuyo nombre es:

5. Composition and functional properties of the essential oil of amazonian basil, Ocimum micranthum Willd.,Labiatae in comparision with commercial essential oil.

En resumen, las revistas internacionales en donde la Universidad Politécnica a participado, institucionalmente o aportando investigadores serían:

- Food Chemistry, 85, 415-421 (2004) (Food \& Science Technology, 15/92, 1.396).

- Journal of Ethnopharmacology, in press.

- Mycological Research, spedito (2005).

- Flavour and Fragance, 17 mar 2006

- Agricultural and Food Chemistry, 52, 3486 - 3491 (2004).

Finalmente, pongo a consideración tres de los cinco abstracs, y el compromiso para fomentar y continuar con este trabajo y, sobre todo, tal como señala el título de este pequeño artículo, comprender la relación que existe entre docencia e investigación y su enorme importancia, en el quehacer universitario.

Revista Food Chemistry.

Mayo 2004. 


\section{Chemical composition and biological activities of Ishpingo essential oil, a traditional Ecuadorian spice from Ocotea quixos (Lam.) Kosterm. (Lauraceae) flower calices}

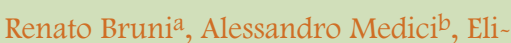
sa Andreottib, Carlo Fantinc, Mariavit toria Muzzolib, Marco Dehesa ${ }^{\mathrm{d}}$, Carlo Romagnolie and Gianni Sacchettib

Received 4 April 2003; revised 15 July 2003; accepted 15 July 2003. ; Available online 6 January 2004.

\section{Abstract}

The essential oil of Ishpingo (Ocotea quixos, Lauraceae) fruit calices was analysed by GC Igas chromatography) and GC-MS Igas chromatography-mass spectrometry). Fourty-four compounds were identified. The main components detected were trans-cinnamaldehyde (27.9\%), methylcinnamate (21.6\%), 1.8-cineole $(8.0 \%)$, benzaldehyde (3.6\%), and_-selinene (2.1\%). In vitro antioxidant properties of the essential oil, obtained by DPPH (1,1-diphenyl-2-picrylhydrazyl) and _-carotene bleaching assays, were also evaluated. The oil exerted a relatively good capacity to act as a non-specific donor of hydrogen atoms or electrons when checked by the diphenylpicrylhydrazyl assay, quenching 52\% of the radical. On the other hand, it showed weak effects in inhibiting oxidation of linoleic acid when assayed by the _-carotene bleaching test. Antibacterial activity of the essential oil was also checked against gram positive (Enterococcus foecalis, Staphylo- coccus aureus) and gram negative strains (Escherichia coli, Pseudomonas aeruginosa). The oil also showed a dose-dependent antifungal activity against Candida albicans, Saccharomyces cerevisiae, phytopathogen Pythium ultimum and dermatophyte Trichophyton mentagrophytes.

Author Keywords: Ocotea quixos; Lauraceae; Essential oil; Antioxidant activity; Antibacterial activity; Antifungal activity; Cinnamaldehyde; Methyl cinnamate

Revista Flavour and Fragance Journal

Publicada el 16 de marzo de 2006

Research Article

a Dipartimento di Biologia Evolutiva e Funzionale, Sez. Biologia Vegetale e orto Botanico, Università degli Studi di Parma, Parco Area delle Scienze 11A, 43100, Parma, Italy.

b Dipartimento delle Risorse Naturali e Culturali, Università degli Studi di Ferrara, C.so Porta Mare 2, 44100, Ferrara, Italy

c Department of Chemistry, University of Ferrara, Via Luigi Borsari 46, I-44100, Ferrara, Italy

d Universidad Politecnica Salesiana, Av. 12 de Octubre 1436 Y Wilson, Quito, Ecuador

e Dipartimento del Museo di Paleobiologia e dell'Orto Botanico, Università degli Studi di Modena e Reggio Emilia, viale dei Caduti in Guerra 127, 41100, Modena, Italy

1 Dipartimento delle Risorse Naturali e Culturali, Università degli Studi di Ferrara, Corso Porta Mare 2, 44100 Ferrara, Italy

2 SISTA, Università degli Studi di Ferrara, Via Fossato di Mortara 47, 44100 Ferrara, Italy

3 Laboratorio Bioquímico, Instituto Technologico Intercultural Bilingüe Salesiano, Sevilla Don Bosco, Macas, Morona Santiago, Ecuador

4 Dipartimento di Biologia Evolutiva e Funzionale, Sezione Biologia Vegetale e orto Botanico, Università degli Studi di Parma, Parco Area delle Scienze 11A, 43100 Parma, Italy email: Renato Bruni (bruni@biol.unipr.it) 


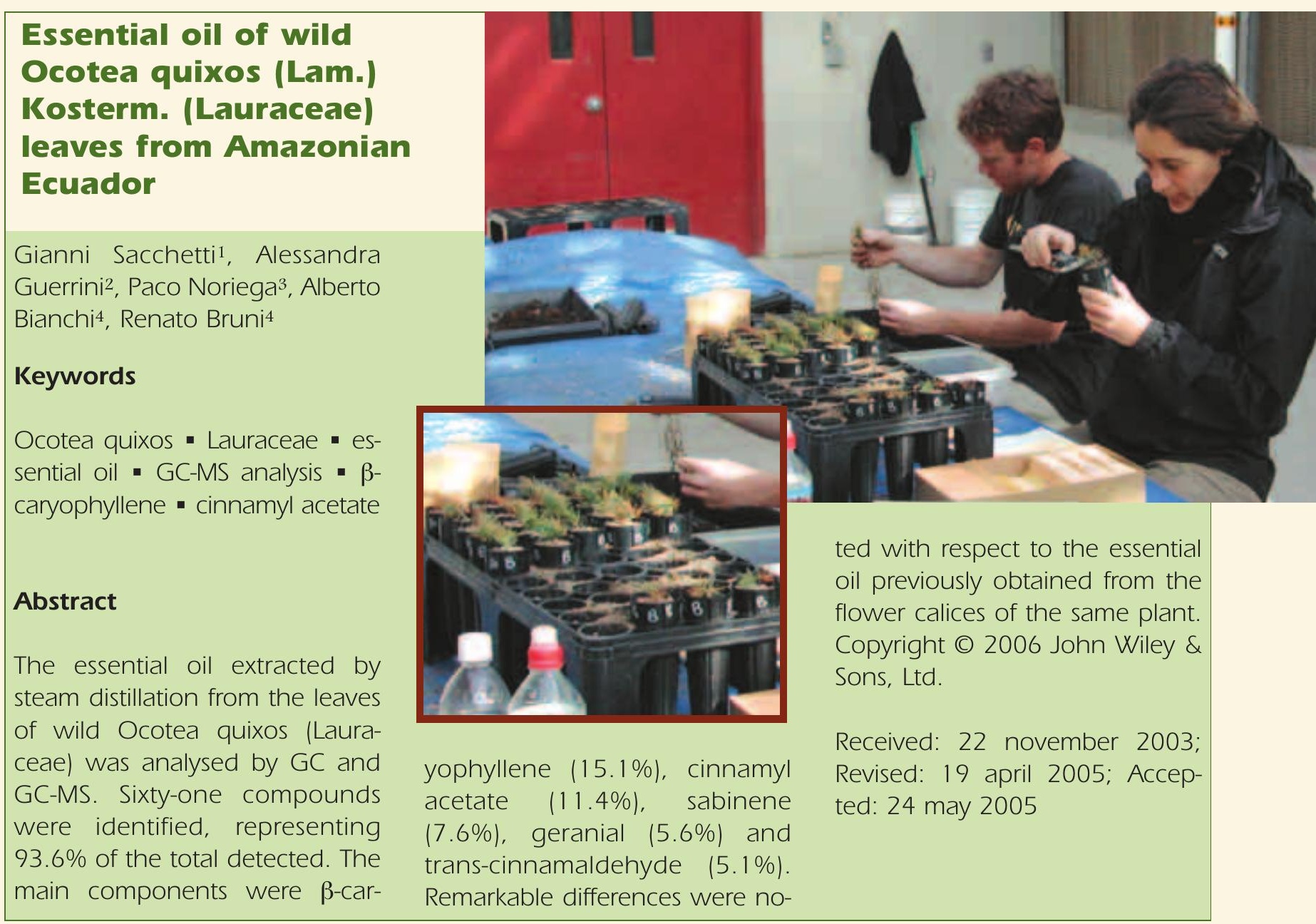

\section{Composition and functional properties of the essential oil of amazonian basil, Ocimum micranthum Willd., Labiatae in comparison with commercial essential oils.}

Sacchetti G, Medici A, Maietti S, Radice M, Muzzoli M, Manfredini S, Braccioli E, Bruni R

Dipartimento delle Risorse Naturali e Culturali, Universita degli Studi di Ferrara, C.so Porta Mare 2, I-44100 Ferrara, Italy.

Wild Amazonian basil Ocimum micranthum Willd. 10 . campechianum Mill.) Labiatae essential oil was analyzed by GC and GCMS: 31 compounds were identified. The main components were eugenol (46.55 +/- 5.11\%), beta-caryophyllene $(11.94$ +/$1.31 \%)$, and beta-elemene (9.06 +/- 0.99\%), while a small amount of linalool $(1.49+/-$ $0.16 \%$ ) was detected. The oil was tested for its in vitro foodrelated biological activities and compared with common basil Ocimum basilicum and Thymus vulgaris commercial essential oils. Radical scavenging activity was evaluated employing 1,1diphenyl-2-picrylhydrazyl (DPPH) assay. The oil exerted a good capacity to act as a nonspecific donor of hydrogen atoms or electrons when checked in the diphenylpicrylhydrazyl assay, quenching 76.61 +/- $0.33 \%$ of the radical, with values higher than those reported by reference oils. In the be- ta-carotene bleaching test, the oil provided an antioxidant efficacy comparable with that of $\mathrm{O}$. basilicum and T. vulgaris essential oils. These data were confirmed by photochemiluminescence, where the oil showed a remarkable antioxidant capacity $(2.39+/-0.1)$, comparable to that of Trolox and vitamin $E$, and higher than the other essential oils. Antibacterial activity of $O$. micranthum essential oil was evaluated against Gram positive and Gram negative bacterial strains. The oil showed a dose-dependent antifungal activity against pathogenic and food spoiling yeasts. 